\title{
Matrix Metalloproteinase Inhibitor RECK Expression in Canine Tumors
}

\author{
Satoshi TAKAGI ${ }^{1)}$, Yuka KATO ${ }^{2)}$, Kazushi ASANO ${ }^{1}$, Tomohiro OHSAKI ${ }^{1)}$, Darko BOSNAKOVSKI ${ }^{1}$, \\ Yuki HOSHINO $^{1)}$, Masahiro OKUMURA ${ }^{1)}$, Tsuyoshi KADOSAWA ${ }^{1)}$ and Toru FUJINAGA ${ }^{1)}$ \\ ${ }^{1)}$ Laboratory of Veterinary Surgery, Department of Clinical Science, Graduate School of Veterinary Medicine, Hokkaido University, \\ Sapporo 060-0818 and ${ }^{25}$ Laboratory of Veterinary Surgery, Department of Veterinary Medicine, College of Bioresource Sciences, Nihon \\ University, Kameino, Fujisawa 252-8510, Japan
}

(Received 20 August 2004/Accepted 14 April 2005)

ABSTRACT. Matrix metalloproteinases (MMPs) selectively degrade the extracellular matrix, and they have been reported to play an important role in tumor invasion, metastasis and angiogenesis. These enzymes are closely related to tumor malignancy and patient survival time. Recently, reversion-inducing cysteine-rich protein with Kazal motifs (RECK) gene was identified as an endogenous membraneanchored MMP inhibitor. The down-regulation of RECK has been implicated in tumor progression. In this study, the expression levels of the RECK messenger ribonucleic acid (mRNA) in various spontaneously developed canine tumors were investigated by using quantitative reverse transcriptase-polymerase chain reaction (RT-PCR), and the correlation between $R E C K$ and clinicopathological factors, as well as MMP-9 expression were analyzed. The median age of 36 dogs investigated in this study was 9 years old (range, $1-15$ years old). Quantitative RT-PCR could detect low levels of expression of RECK mRNA in the tumor samples. The expression levels of RECK mRNA in some tumor tissue samples were significantly lower than those in normal tissue samples. No significant associations of $R E C K$ with clinicopathological factors were observed. Using the Mann-Whitney $U$ test, the expression level of the $M M P-9$ mRNA was observed to be significantly correlated to RECK expression $(p<0.05)$.

KEY WORDS: canine, matrix metalloproteinase, proteinase inhibitor, RECK, tumor malignancy.

J. Vet. Med. Sci. 67(8): 761-767, 2005

Metastasis and invasion of tumor cells are correlated with tumor malignancy. Matrix metalloproteinase (MMP)-2 (72 kilodalton, Gelatinase A) and MMP-9 (92 kilodalton, Gelatinase B) have been reported to play an important role in the pathology of cancer, particularly in invasion, metastasis and angiogenesis. Increased concentrations of gelatinases are associated with poor prognosis of a number of human malignant tumors $[5,15,16]$.

Matrix metalloproteinases are a family of more than 20 zinc-dependent neutral endopeptidases [3]. All MMPs are expressed as proenzymes and are subsequently activated to become proteolytic enzymes [28]. MMPs selectively degrade the extracellular matrix, and gelatinases degrade the type-IV collagen, which is the main component of the basement membrane. The activity of MMPs is closely regulated by endogenous nonspecific (2-macroglobulin) and specific inhibitors (tissue inhibitors of matrix metalloproteinases [TIMP]-1 to -4) [9, 13, 31].

A new endogenous specific MMP inhibitor gene, termed as the reversion-inducing cysteine-rich-protein with Kazalmotifs $(R E C K)$ gene, was recently isolated by cDNA expression cloning. This gene induces flat morphology when expressed in the v-Ki-ras-transformed NIH/3T3 cell line [32]. RECK negatively regulates MMP-2, MMP-9, and membrane-type matrix metalloproteinase (MT1-MMP [MMP-14]) [25, 32]. RECK has been reported to be an endogenous MMP inhibitor and a membrane-anchored glycoprotein (approximately $110 \mathrm{kDa}$ ) with multiple epidermal growth factor-like repeats and serine protease inhibitor-like domains; however, it has no structural homology with TIMPs. The RECK gene was detected in various human tis- sues, but it could not be detected in tumor derived cell lines and oncogene-transformed cells [32]. The down-regulation of RECK has been experimentally implicated in tumor progression and angiogenesis. In addition, patients with hepatocellular carcinoma, breast carcinoma and pancreatic carcinoma showed that high $R E C K$ expression was significantly correlated with long survival time [10, 21, 31].

Spontaneously developing canine tumors are considered to be useful models of human cancer because the survival time in dogs is shorter than that in humans, and the biological behavior of these tumors is very similar to that in humans $[6,18,23]$. In addition, it was reported that in spontaneously developed canine tumors, MMP-2 and MMP-9 expressions might be involved in tumor malignancy, similar to human patients $[17,18]$. In our previous study, we confirmed that the cDNA sequence of canine $R E C K$ was considerably similar to that of mice and humans [33]. Thus, it will be expected that RECK may play an important role in canine tumor malignancy, as it does in humans.

The objective of this study is to investigate the expression of $R E C K$ in various spontaneously developing canine tumors. For this reason, RECK mRNA expression level in different canine tumor specimens was quantified by realtime fluorescence RT-PCR and correlated with clinicopathological factors and $M M P-9$ mRNA expression.

\section{MATERIALS AND METHODS}

Animals and tissue samples: Tissue specimens were obtained from 36 dogs with spontaneously developed canine tumors. The samples were obtained after the dogs 
underwent biopsy or resection of their primary tumors. Normal tissue sections that were apparently distant from primary tumor or tissues obtained from clinically normal dogs were also analyzed. The canine tumors were classified in accordance with the World Health Organization's (WHO) classification system [26]. Immediately after resection, the tissue samples were frozen in liquid nitrogen or stored overnight at $4^{\circ} \mathrm{C}$ in RNA preservation solution (RNAlater; Ambion, Austin, TX, U.S.A.), followed by storage at $-80^{\circ} \mathrm{C}$ until RNA extraction.

$R N A$ extraction and reverse transcription: Total RNA was extracted from the tissue samples by the guanidine isothiocyanate method [4]. The total RNA $(2 \mu \mathrm{g})$ was then denatured at $70^{\circ} \mathrm{C}$ for $10 \mathrm{~min}$, cooled immediately, and added to a solution containing 200 units of M-MLV reverse transcriptase (Invitrogen, Carlsbad, CA, U.S.A.), $50 \mathrm{nmol}$ dithiothreitol, 10 pmol poly (dT) primer and $20 \mathrm{nmol} \mathrm{dNTPs}$ in a total volume of $20 \mu l$. After the poly (dT) primer was annealed at $20^{\circ} \mathrm{C}$ for $10 \mathrm{~min}$, cDNA synthesis was performed at $37^{\circ} \mathrm{C}$ for $1 \mathrm{hr}$.

Quantitative RT-PCR analysis of canine RECK gene: All the PCR reactions were performed using a detection kit (Lightcycler-FirstStart DNA Master SYBR Green kit, Roche Molecular Biochemicals, Mannheim, Germany) [37]. The primers were synthesized to amplify a specific segment of the cDNA sequence of canine RECK and MMP9. In order to ensure the fidelity of mRNA extraction and reverse transcription, and to normalize the samples, all the samples were subjected to PCR amplification with oligonucleotide primers that were specific to the constitutively expressed gene Ribosomal protein S26 (RPS26). The primer sequences for the each gene were as follows: $R E C K$ forward primer, 5'-TCC CTG AAG ACC ACA CAG CT3'; reverse primer, 5'-CAA CCA ACT TCC CCT GCA GA3', MMP-9 forward primer, 5'-CGC TTC TGG AGT TTC GAC GT-3'; reverse primer, 5'GTC CTG GCA GAA GTA GGC TT-3' and RPS26 forward primer, 5'-GCC ATT AAG AAA TTC GTC ATT CG-3'; reverse primer, 5'-CGA GAT CGA TTC CTG ACT AC-3'.

The PCR reaction mixture containing the following reaction components was prepared to the indicated end-concentration: $13.4 \mu l$ water, $2.4 \mu l \mathrm{MgCl}_{2}(4 \mathrm{mM}), 0.1 \mu l$ forward primer $(100 \mu \mathrm{M}), 0.1 \mu l$ reverse primer $(100 \mu \mathrm{M})$ and $2.0 \mu l$ LightCycler Fast Start DNA Master SYBR Green I (Roche Molecular Biochemicals). As a PCR template, $18 \mu \mathrm{l}$ of master-mix and $2 \mu l$ of cDNA as a PCR template were added to glass capillaries.

The cycling conditions were as follows; initial denaturation at $95^{\circ} \mathrm{C}$ for $30 \mathrm{sec}$, followed by 35 cycles $(R E C K$, $M M P-9)$ or 30 cycles (RPS26) at $95^{\circ} \mathrm{C}$ for $0 \mathrm{sec}, 60^{\circ} \mathrm{C}$ for 5 $\mathrm{sec}$, and $72^{\circ} \mathrm{C}$ for $10 \mathrm{sec}$. In order to improve the SYBR Green I quantification, the temperature of the fluorescence measurement point was set at $84^{\circ} \mathrm{C}(R E C K), 85^{\circ} \mathrm{C}(M M P$ $9)$, and $83^{\circ} \mathrm{C}(R P S 26)$, respectively. The expression level of each mRNA in the tissue samples was determined relative to the standard curve by using the LightCycler computer software (Roche Molecular Biochemicals). The identity of each
PCR product was confirmed by electrophoresis.

The expression of the RECK mRNA in five canine tumor cell lines (mast cell tumor [12], mammary gland tumor, transitional cell carcinoma, osteosarcoma [14], and high metastatic osteosarcoma [1]) was also analyzed by quantitative RT-PCR method.

Gelatin zymography: Using a previously reported method, gelatin zymography was performed to measure the production and activity of gelatinases obtained from tumor cell lines in the conditioned media $[2,36]$. Briefly, $20 \mu l$ of supernatant of each conditioned medium was mixed with an equal volume of 2x SDS-PAGE sample buffer without boiling. The samples were fractionated using electrophoresis in a $10 \%$ polyacrylamide gel containing gelatin $(0.5 \mathrm{mg} / \mathrm{m} l)$. In order to remove the SDS, the gels were soaked in $2.5 \%$ Triton X-100 containing $10 \mathrm{mM}$ Tris (pH8.0) for $30 \mathrm{~min}$ at room temperature, and incubated in a digestion buffer $(50$ $\mathrm{mM}$ Tris [pH 8.0], $0.5 \mathrm{mM} \mathrm{CaCl}_{2}$ and $1 \mu \mathrm{M} \mathrm{ZnCl}_{2}$ ) at $37^{\circ} \mathrm{C}$ for $30 \mathrm{hr}$, to enable the proteinase digestion of the substrate. The gels were stained with $0.25 \%$ Coomassie brilliant blue R-250 and destained with 10\% isopropanol and 5\% acetic acid. The gelatinolytic activities appeared as clear bands of digested gelatin against a dark blue background of stained gelatin.

Statistical analysis: The differences between the RECK mRNA expression level in normal and concurrent tumor tissue specimens were assessed by the nonparametric MannWhitney $U$ test. For statistical purposes, the undetectable RECK mRNA expression level was set at 0 . The correlation between the RECK mRNA expression and clinicopathological parameters were tested with the nonparametric MannWhitney $U$ test or Kruskal-Wallis test. The RECK mRNA expression level in different tumors was tested with the nonparametric Kruskal-Wallis test. The Pearson's correlation coefficient test was used to evaluate the association between the $R E C K$ mRNA expression and the $M M P-9$ mRNA expression. The statistical analyses were performed using the Stat View 5.0 software (SAS Institute, Cary, NC, U.S.A.).

\section{RESULTS}

Animals: Tissue samples were obtained from 36 dogs, including 20 uncastrated males, 4 castrated males, 11 unspayed females, and 1 spayed female. The median age of the dogs was 9 years (range, 1-15 years) (Table 1). The dogs were of the following breeds: mixed breed dogs $(n=12)$, Golden Retriever $(n=6)$, Siberian Husky $(n=3)$, Beagle $(n=2)$, Pomeranian $(n=2)$, Shetland Sheep Dog $(n=2)$, and one each of the Bernese Mountain Dog, Cavalier King Charles Spaniel, Labrador Retriever, Maltase, Miniature Dachshund, Miniature Schnauzer, Samoyed, Shih Tzu, and Welsh Corgi.

RECK $m R N A$ expression in tumor and normal tissue samples: The expression levels of the RECK mRNA in tumor and normal tissues were compared (Fig. 1). In osteosarcoma and hemangiosarcoma tissues, there was no signifi- 
Table 1. Clinical deta of tumor bearing dogs and RECK/RPS26 value in various canine tumor tissues

\begin{tabular}{|c|c|c|c|c|c|c|c|c|}
\hline \multirow{2}{*}{ Case } & \multirow{2}{*}{ Tumor Type } & \multirow{2}{*}{ Age } & \multirow{2}{*}{ Sex } & \multicolumn{2}{|c|}{ Metastasis } & \multirow{2}{*}{ TumorLocation } & \multirow{2}{*}{ TumorStage } & \multirow{2}{*}{ RECK/RPS26 } \\
\hline & & & & Lymph Node & Distant & & & \\
\hline 1 & HPC & 9 & $\mathrm{f}$ & - & - & skin & T2N0M0 & 5.6234 \\
\hline 2 & HPC & 8 & $\mathrm{f}$ & - & - & skin & T2N0M0 & 2.3143 \\
\hline 3 & HPC & 11 & $\mathrm{~m}$ & - & - & skin & T2N0M0 & 0.5785 \\
\hline 4 & HPC & 10 & $\mathrm{f}$ & - & - & skin & T3N0M0 & 3.9679 \\
\hline 5 & HPC & 15 & $\mathrm{~m}$ & - & - & skin & T3N0M0 & 0.2143 \\
\hline 6 & HPC & 8 & $\mathrm{f}$ & - & - & skin & T3N0M0 & 0.4413 \\
\hline 7 & HPC & 8 & $\mathrm{~m}$ & - & - & skin & T3N0M0 & 4.0142 \\
\hline 8 & HPC & 13 & $\mathrm{f}$ & - & - & skin & T3N2aM0 & 12.1291 \\
\hline 9 & HPC & 9 & $\mathrm{f}$ & - & - & skin & T4N0M0 & 0.1296 \\
\hline 10 & HPC & 7 & $\mathrm{c}$ & - & - & skin & T4N1aM0 & 0.4298 \\
\hline 11 & HS & 5 & $\mathrm{~m}$ & + & - & skin & T3N1bM0 & 2.7561 \\
\hline 12 & HS & 6 & $\mathrm{c}$ & - & - & spleen & - & 0.6765 \\
\hline 13 & HS & 4 & $\mathrm{~m}$ & - & + & spleen & - & 1.4248 \\
\hline 14 & HS & 9 & $\mathrm{~m}$ & + & - & spleen & - & 1.8044 \\
\hline 15 & HS & 10 & $\mathrm{~s}$ & - & + & spleen & - & 11.3482 \\
\hline 16 & OS & 1 & $\mathrm{~m}$ & + & - & bone & T1M0 & 0.5127 \\
\hline 17 & OS & 9 & $\mathrm{~m}$ & - & - & bone & $\mathrm{T} 2 \mathrm{M} 0$ & 0.3306 \\
\hline 18 & OS & 3 & $\mathrm{~m}$ & - & - & bone & $\mathrm{T} 2 \mathrm{M} 0$ & 0.0194 \\
\hline 19 & OS & 8 & $\mathrm{f}$ & - & + & bone & $\mathrm{T} 2 \mathrm{M} 1$ & 6.2455 \\
\hline 20 & OS & 9 & $\mathrm{~m}$ & - & + & bone & T2M1 & 26.3755 \\
\hline 21 & SCC & 2 & $\mathrm{f}$ & + & - & oral & StageIII & 3.3494 \\
\hline 22 & SCC & 9 & $\mathrm{~m}$ & - & - & oral & StageIII & 2.7255 \\
\hline 23 & SCC & 8 & $\mathrm{f}$ & - & - & skin & T2N1bM0 & 9.7039 \\
\hline 24 & SCC & 8 & $\mathrm{~m}$ & + & - & nasal & T2N1bM0 & 0.0903 \\
\hline 25 & $\mathrm{MCT}$ & 5 & $\mathrm{~m}$ & - & - & skin & StageIb & 0.0000 \\
\hline 26 & MCT & 12 & $\mathrm{~m}$ & - & - & skin & StageIIIa & 0.0000 \\
\hline 27 & MCT & 13 & $\mathrm{f}$ & - & - & skin & StageIIIb & 0.0000 \\
\hline 28 & MCT & 13 & $\mathrm{c}$ & - & + & skin & StageIV & 0.0000 \\
\hline 29 & MM & 13 & $\mathrm{~m}$ & + & - & oral & StageIII & 15.8476 \\
\hline 30 & $\mathrm{MM}$ & 12 & $\mathrm{f}$ & + & + & oral & StageIV & 0.0519 \\
\hline 31 & PAGA & 13 & $\mathrm{~m}$ & - & - & skin & T2N0M0 & 0.0695 \\
\hline 32 & PAGC & 10 & $\mathrm{~m}$ & - & - & skin & T3N0M0 & 0.0584 \\
\hline 33 & AGC & 9 & $\mathrm{~m}$ & + & - & skin & T4N2aM0 & 0.6446 \\
\hline 34 & FS & 9 & $\mathrm{~m}$ & + & - & oral & StageIII & 0.4569 \\
\hline 35 & $\mathrm{HCC}$ & 15 & $\mathrm{~m}$ & - & - & liver & T3N0M0 & 0.9676 \\
\hline 36 & TCC & 10 & $\mathrm{c}$ & + & - & bladder & $\mathrm{T} 2 \mathrm{~N} 1 \mathrm{M} 0$ & 0.0081 \\
\hline
\end{tabular}

HPC; Hemangiopericytoma, HS; Hemangiosarcoma, OS; Osteosarcoma, SCC; Squamous cell carcinoma, MCT; Mast Cell Tumor, MM; Malignant Melanoma, PAGA; Perianal Gland Adenoma, PAGC; Perianal Gland Adenocarcinoma, AGC; Apocrine Gland Carcinoma, FS; Fibrosarcoma, HCC; Hepatocellular Carcinoma, TCC; Transitional Cell Carcinoma. $\mathrm{m}$; intact male, c; castrated male, f; intact female, s; spayed female.

cant correlation between normal and tumor tissues. In hemangiopericytoma and skin tumor, the RECK mRNA expression in the tumor tissues was significantly lower than that in normal tissues $(p<0.05)$. In hepatocellular carcinoma, the $R E C K$ mRNA expression was low in the tumor tissues when compared with that in normal liver tissues.

RECK $m R N A$ expression in different tumor types: The results of histopathological examination of the 36 tumor tissues and RECK/RPS26 are listed in Table 2. The nonparametric Kruskal-Wallis test revealed no statistical difference among the various tumors ( $p=0.084)$. Among these tumors, RECK mRNA expression could not be detected only in all of the mast cell tumors (MCT, $\mathrm{n}=4$ ).

The RECK mRNA expression in tumor cell lines was also examined. Among all the tumor cell lines, the cell line of osteosarcoma showed significantly high $R E C K$ expression $(p<0.05)$.
Correlation of RECK $m R N A$ expression with clinicopathological features and MMP-9 $\mathrm{mRNA}$ expression in the dogs: The Mann-Whitney $U$ test and the Kruskal-Wallis test revealed that there was no significant difference in the clinicopathological variables, including age, sex, existence of lymph node metastasis, and distant metastasis (Table 3). Distant metastasis was confirmed in the lung (osteosarcoma, melanoma), heart, and liver (hemangiosarcoma). MMP-9 mRNA expression level was significantly correlated to the $R E C K$ mRNA expression ( $p=0.022)$ (Table 3). However, on analysis by the Pearson's correlation coefficient test, no correlation between them was observed, and the value of correlation coefficient was -0.037 ( $p=0.842$ ) (Fig. 2).

Gelatin zymography: Variable levels of pro-MMP-2 and pro-MMP-9 were detected in the conditioned medium. MMP-9 was significantly activated in the transitional cell carcinoma cell line. The secretion of gelatinase in osteosar- 

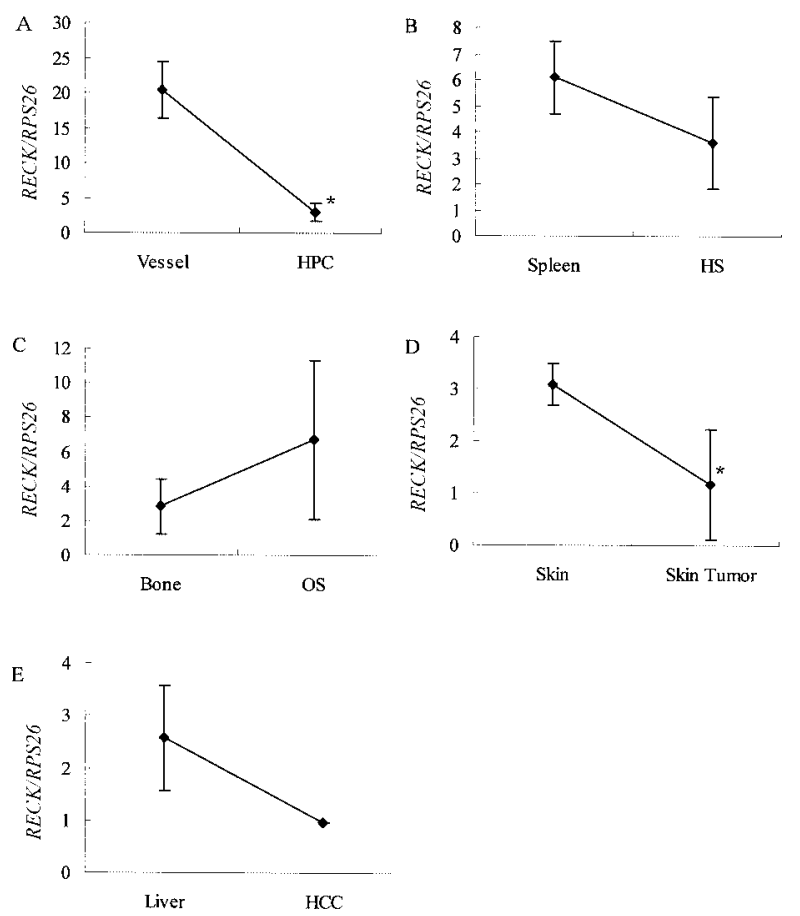

Fig. 1. Levels of the RECK/RPS26 expression in canine tumor tissues and original normal tissues. A: Hemangiopericytoma (HPC), B: Hemangiosarcoma (HS), C: Osteosarcoma (OS), D: Skin tumor, E: Hepatocellular Carcinoma (HCC). In hemangiopericytoma and skin tumor, the RECK expression in the tumor tissues were significantly lower than that in normal tissues by Mann-Whitney $U$ test $\left({ }^{*} \mathrm{p}<0.05\right)$. (RECK: reversion-inducingcysteine-rich protein with Kazal motifs, RPS26: ribosomal potein $S 26$ ) Bar: mean value \pm standard error.

Table 2. RECK/RPS26 value in various canine tumors and tumor cell lines

\begin{tabular}{lcl}
\hline \multirow{2}{*}{ Tumor Type } & $\begin{array}{c}\text { Number of } \\
\text { cases }\end{array}$ & \multicolumn{1}{c}{ RECK/RPS26 } \\
\cline { 3 - 3 } & & Mean \pm S.E. \\
\hline Clinical Case & 10 & $2.9800 \pm 1.1910$ \\
Hemangiopericytoma & 5 & $3.6020 \pm 1.9653$ \\
Hemangiosarcoma & 5 & $6.6967 \pm 5.0538$ \\
Osteosarcoma & 4 & Undetectable \\
Mast Cell Tumor & 4 & $3.9673 \pm 2.0385$ \\
Squamous cell carcinoma & 2 & 7.9498 \\
Malignant Melanoma & 1 & 0.0695 \\
Apocrine Gland Adenocarcinoma & 1 & 0.4569 \\
Fibrosarcoma & 1 & 0.9676 \\
Hepatocellular Carcinoma & 1 & 0.0584 \\
Perianal Gland Adenocarcinoma & 1 & 0.0081 \\
Transitional Cell Carcinoma & 1 & 0.0695 \\
Perianal Gland Adenoma & & \\
\hline Tumor Cell Lines & 3 & $0.0603 \pm 0.0247$ \\
Mast Cell Tumor & 3 & $0.2761 \pm 0.1568$ \\
Mammary Gland Tumor & 3 & $0.1115 \pm 0.0383$ \\
Transitional Cell Carcinoma & 3 & $1.1762 \pm 0.0820$ \\
Osteosarcoma & 3 & $0.4297 \pm 0.1119$ \\
High Metastatic Osteosarcoma &
\end{tabular}

S.E.: Standard Error coma was low as compared to that in other tumor cell lines (Fig. 3).

\section{DISCUSSION}

In the present study, expression of endogenous MMP inhibitor RECK was investigated in various spontaneously developing canine tumors. The quantification of RECK mRNA is reported to be an effective prognostic marker in human hepatocyte carcinoma [10], breast carcinoma [30], and pancreatic carcinoma [21]. In most of the previous studies, the expression level of the RECK mRNA was quantified by Northern blotting [10, 2132$]$. In these studies, the expression level was observed to be considerably low in normal human tissues and tumor cell lines. Therefore, the purification of poly A (+) mRNA from the total RNA was necessary in order to detect the low expression of the RECK mRNA by Northern blotting, and a large amount of samples was required for purification. The quantitative RT-PCR used in this study is an easy and useful method to measure the mRNA of specific genes, and it is suitable for treating a large number of samples. Moreover, it can be performed with a small amount of tissue sample.

A majority of tumor tissues showed low levels of RECK mRNA expression as compared to normal tissues. However, the expression of RECK mRNA in some tumor tissues was detected to be higher than that in normal tissues. The higher expression in the tumor tissues is inconsistent with the fact that the expression of the $R E C K$ gene is suppressed in rodent and human tumor-derived cell lines [32]. In this study, RECK mRNA expression was also suppressed in a majority of the canine tumor cell lines. One explanation for this suppression is that the selection of RECK-negative populations occurs due to the culture passaging, which may be result in suppression of RECK mRNA. The other explanation is that specific stimulus may affect the RECK expression in vivo or in vitro. For example, stromal cells affect RECK expression in tumor cells either directly or by secreting growth factors.

Among all the analyzed sample, those obtained from a normal vessel showed the highest RECK mRNA expression. This may be due to the fact that RECK was proven to show high expression in perivascular smooth muscle cells [25]. The tumor vessels have no perivascular smooth muscle cells [7]; therefore, RECK mRNA expression in tumor tissues was generally regarded to be low. Considering this fact, there was a possibility that preeminent $R E C K$ mRNA expression in tumor tissues were caused by the contamination of perivascular smooth muscle cells.

A slight significant difference was observed in the $R E C K$ mRNA expression in various tumor types. However, $R E C K$ expression in osteosarcoma was considered to be higher than that in other tumors. The RECK mRNA expression in the osteosarcoma cell line was significantly higher than that in other tumor cell lines, and it inclined to be higher in the spontaneously developed osteosarcoma. The RECK expression levels could differ depending on the type of tumor. A 
Table 3. Comparison between clinicopathological features and RECK/RPS26 value

\begin{tabular}{clcccc}
\hline Factor & Category & Cases & $(\%)$ & RECK/RPS26 Median & $p$ \\
\hline Age $^{\text {a) }}$ & $<5$ years old & 6 & $(16.7)$ & 0.97 & \multirow{2}{*}{ N.S. (0.656) } \\
& $\geq 5$ years old & 30 & $(83.3)$ & 0.61 & \\
& intact male & 20 & $(55.6)$ & 0.55 & N.S. (0.130) \\
& castrated male & 4 & $(11.1)$ & 0.22 & \\
& intact female & 11 & $(30.6)$ & 3.35 & 11.35 \\
& spayed female & 1 & $(2.8)$ & 0.64 & \multirow{2}{*}{ N.S. (0.784) } \\
& metastasis & 10 & $(27.8)$ & 0.58 & \multirow{2}{*}{ N.S. (0.384) } \\
\hline Regional lymph node $^{\text {a) }}$ & normal & 26 & $(72.2)$ & 8.80 & \multirow{2}{*}{0.022} \\
\hline Distant metastasis & metastasis & 6 & $(16.7)$ & 0.48 & \\
\hline MMP-9/RPS26 & normal & 30 & $(83.3)$ & 0.13 & 1.80 \\
\hline
\end{tabular}

MMP-9: Matrix metalloproteinase-9, N.S.: Not significant.

a) $p$ for Mann-Whitney $U$ test, b) $p$ for Kruskal-Wallis test.

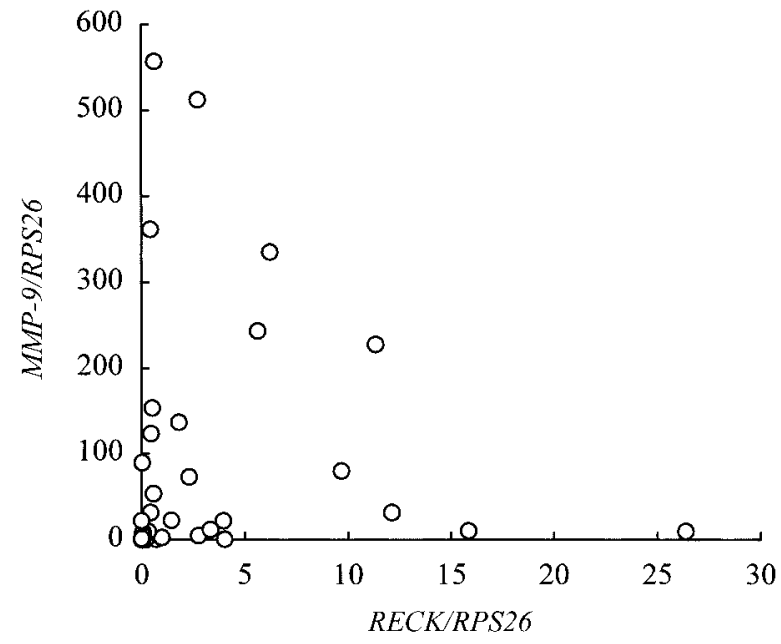

Fig. 2. The correlation between $R E C K$ and $M M P-9$ expression in messenger ribonucleic acid level. The RECK and the $M M P-9$ expression levels were evaluated by Pearson's correlation coefficient test. No significant correlation was observed $(p=0.842)$.

large number of tumor tissue samples needs to be analyzed in order to evaluate the possible differences of $R E C K$ mRNA expression in various tumors.

The RECK mRNA could not be detected in all the MCT samples using the quantitative RT-PCR analysis. Canine MCT is known to be a highly infiltrative tumor, and very wide margin is needed for complete resection [34]. Highly invasive tumors were expected to show low RECK mRNA expression and high MMP-9 mRNA expression. Thus, MCT may have a MMPs regulation mechanism that is different from the RECK pathway. This result indicates that the RECK mRNA expression level is not effective as a prognostic marker in canine MCT.

In the present study, no MCTs showed a high MMP-9 mRNA expression. On the other hand, gelatin zymography showed the secretion of pro-MMP-9 from MCT cells. This result may be related to the fact that RECK has been shown to inhibit pro-MMP-9 secretion and activation but not the production [32].

The Pearson's correlation coefficient test revealed that the RECK mRNA expression in hepatocellular carcinoma was significantly and positively correlated with $M M P-9$ expression. Moreover, the expression levels of RECK and MMP-9 were similar at mRNA level and at protein level [21]. The correlation between these two factors was also investigated in canine tumors. The Mann-Whitney $U$ test revealed that the levels of $M M P-9$ and $R E C K$ mRNA expression correlated significantly and positively; however, no correlation was observed by the Pearson's correlation coefficient test. The RECK transfection in cultured cell had not been proven to affect $M M P-9$ mRNA expression, and was reported to suppress pro-MMP-9 secretion and activation [32]. In the present study, a positive correlation of $M M P-9$ and RECK expression may be determined based on the MMP-9 expression in the inflammatory cell. Another possibility is that these two genes are regulated by a common mechanism. The expression of the RECK gene was observed to be regulated by $\mathrm{Sp} 1$ transcriptional factors, in a manner same as that for MMP-9 [8, 27, 29].

TIMPs are also endogenous MMP inhibitors and their higher expression results in the poor prognosis of human breast carcinoma, colon carcinoma, and stomach carcinoma $[19,22]$. The difference between RECK and TIMPs is in their localization; RECK is membrane anchored, whereas TIMPs are secreted. Thus far, the tumor promoting mechanism of TIMPs is relatively unclear. The function of TIMPs is to inhibit MMPs [20]; however, they also act as growth factors of tumors $[11,24,35]$. In comparison with TIMPs, RECK has been reported to be an effective prognosis marker in human patients and a similar condition [10, 21, $31]$ was expected in dogs. Further study is required to determine the usefulness of RECK as a prognostic marker in canine spontaneously developed tumors. 


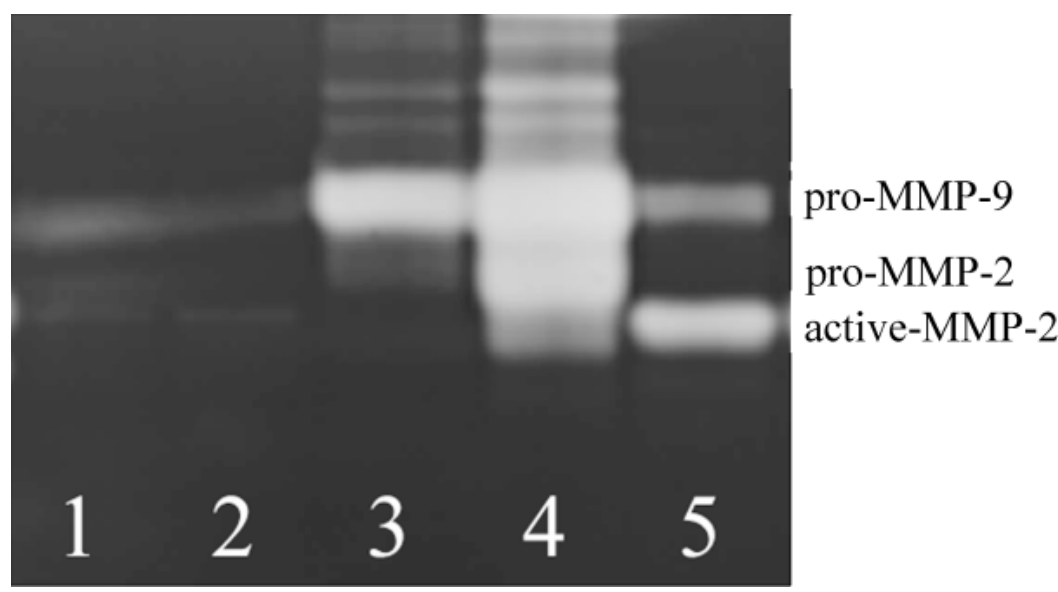

Fig. 3. The gelatin zymography in tumor cell lines. lane 1; high metastatic osteosarcoma, lane 2; osteosarcoma, lane 3; mast cell tumor, lane 4; transitional cell carcinoma, lane 5; mammary gland tumor.

ACKNOWLEDGEMENTS. The authors are grateful to Prof. M. Saitoh (Laboratory of Veterinary Biochemistry, Department of Clinical Science, Graduate School of Veterinary Medicine, Hokkaido University) for providing experimental instrument.

\section{REFERENCES}

1. Barroga, E. F., Kadosawa, T., Okumura, M. and Fujinaga, T. 1999. Establishment and characterization of the growth and pulmonary metastasis of a highly lung metastasizing cell line from canine osteosarcoma in nude mice. J. Vet. Med. Sci. 61: 361-367.

2. Becerril, C., Pardo, A., Montano, M., Ramos, C., Ramirez, R. and Selman, M. 1999. Acidic fibroblast growth factor induces an antifibrogenic phenotype in human lung fibroblasts. $\mathrm{Am}$. J. Respir. Cell. Mol. Biol. 20: 1020-1027.

3. Cawston, T. E. 1996. Metalloproteinase inhibitors are the prevention of connective tissue breakdown. Pharmacol. Ther. 70: 163-182.

4. Chomczynski, P. and Sacchi, N. 1987. Single-step method of RNA isolation by acid guanidinium thiocyanate-phenol-chloroform extraction. Anal. Biochem. 162: 156-159.

5. Dalberg, K., Eriksson, E. and Enberg, U. 2000. Gelatinase A, membrane type 1 matrix metalloproteinase, and extracellular matrix metalloproteinase inducer mRNA expression: correlation with invasive growth of breast cancer. World J. Surg. 24: 334-340.

6. de las Mulas, M. J., Ordas, J., Millan, Y., Fernandez-Soria, V. and Ramony, C. S. 2003. Oncogene HER-2 in canine mammary gland carcinomas: an immunohistochemical and chromogenic in situ hybridization study. Breast Cancer Res. Treat. 80: $363-367$.

7. Eberhard, A., Kahlert, S., Goede, V., Hemmerlein, B., Plate, K. H. and Augustin, H. G. 2000. Heterogeneity of angiogenesis and blood vessel maturation in human tumors: implications for antiangiogenic tumor therapies. Cancer Res. 60: 1388-1393.

8. Farina, A. R., Tacconelli, A., Vacca, A., Maroder, M., Gulino, A. and Mackay, A. R. 1999. Transcriptional up-regulation of matrix metalloproteinase-9 expression during spontaneous epithelial to neuroblast phenotype conversion by SK-N-SH neuroblastoma cells, involved in enhanced invasivity, depends upon GT-box and nuclear factor kappaB elements. Cell Growth Differ. 10: 353-367.

9. Foda, H. D. and Zucker, S. 2001. Matrix metalloproteinases in cancer invasion, metastasis and angiogenesis. Drug Discov. Today 9: 478-482.

10. Furumoto, K., Arii, S., Mori, A., Furuyama, H., Gorrin Rivas, M. J., Nakao, T., Isobe, N., Murata, T., Takahashi, C., Noda, M. and Imamura, M. 2001. RECK gene expression in hepatocellular carcinoma: correlation with invasion-related clinicopathological factors and its clinical significance. Reverseinducing-cysteine-rich protein with Kazal motifs. Hepatology 33: 189-195.

11. Gasson, J. C., Golde, D. W., Kaufman, S. E., Westbrook, C. A., Hewick, R. M., Kaufman, R. J., Wong, G. G., Temple, P. A., Leary, A. C. and Brown, E. L. 1985. Molecular characterization and expression of the gene encoding human erythroidpotentiating activity. Nature (Lond.) 315: 768-771.

12. Ishiguro, T., Kadosawa, T., Mori, K., Takagi, S., Okumura, M. and Fujinaga, T. 2001. Establishment and characterization of a new canine mast cell tumor cell line. J. Vet. Med. Sci. 63: 1031-1034.

13. John, A. and Tuszynski, G. 2001. The role of matrix metalloproteinases in tumor angiogenesis and tumor metastasis. Pathol. Oncol. Res. 7: 14-23.

14. Kadosawa, T., Nozaki, K., Sasaki, N. and Takeuchi, A. 1994. Establishment and characterization of a new cell line from a canine osteosarcoma. J. Vet. Med. Sci. 56: 1167-1169.

15. Kawamata, H., Uchida, D. and Hamano, H. 1998. ActiveMMP2 in cancer cell nests of oral cancer patients: correlation with lymph node metastasis. Int. J. Oncol. 13: 699-704.

16. Kawano, N., Osawa, H. and Takaaki, I. 1997. Expression of gelatinase $\mathrm{A}$, tissue inhibitor of metalloproteinases-2, matrilysin, and trypsin(ogen) in lung neoplasms. Hum. Pathol. 28: 613-622.

17. Lana, S. E., Oglivie, G. K., Hnsen, R. A., Powers, B. E., Dernell, W. S. and Withrow, S. J. 2000. Identification of matrix metalloproteinases in canine neoplastic tissue. Am. J. Vet. Res. 
61: 111-114.

18. Loukopoulos, P., Mungall, B. A., Straw, R. C., Thornton, J. R. and Robinson, W. F. 2003. Matrix metalloproteinase-2 and -9 involvement in canine tumors. Vet. Pathol. 40: 382-394.

19. Lu, X. Q., Levy, M., Weinstein, I. B. and Santella, R. M. 1991. Immunological quantitation of levels of tissue inhibitor of metalloproteinase-1 in human colon cancer. Cancer Res. 51: 62316235 .

20. Mannello, F. and Gazzanelli, G. 2001. Tissue inhibitors of metalloproteinases and programmed cell death: conundrums, controversies and potential implications. Apoptosis 6: 479-482.

21. Masui, T., Doi, R., Koshiba, T., Fujimoto, K., Tsuji, S., Nakajima, S., Koizumi, M., Toyoda, E., Tulachan, S., Ito, D., Kami, K., Mori, T., Wada, M., Noda, M. and Imamura, M. 2003. RECK expression in pancreatic cancer: its correlation with lower invasiveness and better prognosis. Clin. Can. Res. 9: 1779-1784.

22. Mimori, K., Mori, M., Shiraishi, T., Fujie, T., Baba, K., Haraguchi, M., Abe, R., Ueo, H. and Akiyoshi, T. 1997. Clinical significance of tissue inhibitor of metalloproteinase expression in gastric carcinoma. Br. J. Cancer 76: 531-536.

23. Mohammed, S. I., Bennett, P. F., Craig, B. A., Glickman, N. W., Mutsaers, A. J., Snyder, P. W., Widmer, W. R., DeGortari, A. E., Bonney, P. L. and Knapp, D. W. 2002. Effects of the cyclooxygenase inhibitor, piroxicam, on tumor response, apoptosis, and angiogenesis in a canine model of human invasive urinary bladder cancer. Cancer Res. 62: 356-358.

24. Nagase, H., Suzuki, K., Itoh, Y., Kan, C. C., Gehring, M. R., Huang, W. and Brew, K. 1996. Involvement of tissue inhibitors of metalloproteinases (TIMPS) during matrix metalloproteinase activation. Adv. Exp. Med. Biol. 389: 23-31.

25. Oh, J., Takahashi, R., Kondo, S., Mizoguchi, A., Adachi, E., Sasahara, R. M., Nishimura, S., Imamura, Y., Kitayama, H., Alexander, D. B., Ide, C., Horan, T. P., Arakawa, T., Yoshida, H., Nishikawa, S., Itoh, Y., Seiki, M., Itohara, S., Takahashi, C. and Noda, M. 2001. The membrane-anchored MMP inhibitor RECK is a key regulator of extracellular matrix integrity and angiogenesis. Cell 107: 789-800.

26. Owen, L. N. 1980. TNM classification of tumors in domestic animals, 1st ed., (Owen, L. N., ed.), World Health Organization, Geneva, Switzerland.

27. Sasahara, R. M., Takahashi, C. and Noda, M. 1999. Involvement of the $\mathrm{Sp} 1$ site in ras-mediated downregulation of the RECK metastasis suppressor gene. Biochem. Biophys. Res. Commun. 264: 668-675.

28. Sato, H., Kida, Y., Mai, M., Endo, Y., Sasaki, T., Tanaka, J. and Seiki, M. 1992. Expression of genes encoding type IV collagen-degrading metalloproteinases and tissue inhibitors of metalloproteinases in various human tumor cells. Oncogene 7: 77-83.

29. Sato, H. and Seiki, M. 1993. Regulatory mechanism of $92 \mathrm{kDa}$ type IV collagenase gene expression which is associated with invasiveness of tumor cells. Oncogene 8: 395-405.

30. Span, P. N., Sweep, C. G., Manders, P., Beex, L. V., Leppert, D. and Lindberg, R. L. 2003. Matrix metalloproteinase inhibitor reversion-inducing cysteine-rich protein with Kazal motifs: a prognostic marker for good clinical outcome in human breast carcinoma. Cancer 97: 2710-2715.

31. Stetler-Stevenson, W. G. 2001. The role of matrix metalloproteinases in tumor invasion, metastasis, and angiogenesis. Surg. Oncol. Clin. New. Am. 10: 383-392.

32. Takahashi, C., Sheng, Z., Horan, T. P., Kitayama, H., Maki, M., Hitomi, K., Kitaura, Y., Takai, S., Sasahara, R. M., Horimoto, A., Ikawa, Y., Ratzkin, B. J., Arakawa, T. and Noda, M. 1998. Regulation of matrix metalloproteinase- 9 and inhibition of tumor invasion by the membrane-anchored glycoprotein RECK. Proc. Natl. Acad. Sci. U.S.A. 95: 13221-13226.

33. Takagi, S., Kitamura, T., Hosaka, Y., Ohsaki, T., Bosnakovski, D., Kadosawa, T., Okumura, M. and Fujinaga, T. 2004. Molecular cloning of canine membrane-anchored inhibitor of matrix metalloproteinase, RECK. J. Vet. Med. Sci. (in press)

34. Thamm, D. H. and Vail, D. M. 2001. Mast cell tumors. pp. 261-282. In: Small Animal Clinical Oncology, 3rd ed. (Withrow, S. J. and MacEwin, E. G., eds.), W. B. Saunders, Philadelphia.

35. Toth, M., Bernardo, M. M., Gervasi, D. C., Soloway, P. D., Wang, Z., Bigg, H. F., Overall, C. M., DeClerck, Y. A., Tschesche, H., Cher, M. L., Brown, S., Mobashery, S. and Fridman, R. 2000. Tissue inhibitor of metalloproteinase (TIMP)-2 acts synergistically with synthetic matrix metalloproteinase (MMP) inhibitors but not with TIMP-4 to enhance the (membrane type 1)-MMP-dependent activation of proMMP-2. J. Biol. Chem. 275: 41415-41423.

36. Tsuruda T., Boerrigter G., Huntley B.K., Noser J.A., Cataliotti A., Costello-Boerrigter L.C., Chen H.H. and Burnett Jr. J.C. 2002. Brain natriuretic peptide is produced in cardiac fibroblasts and induces matrix metalloproteinases. Circ. Res. 91: $1127-1134$.

37. Wittwer, C. T., Ririe, K. M., Andrew, R. V., David, D. A., Gundry, R. A. and Balis, U. J. 1997. The LightCycler: a microvolume multisample fluorimeter with rapid temperature control. Biotechniques 22: 176-181. 